\title{
Evidence of the Positive Impact of South-South Cooperation in the Field of Natural Resources: The Specific Case of Sino-Central African Relations
}

\author{
Mario Azou-Passonda ${ }^{*}$, Wei Hong1, Dalin-Kpana Fami Ferdinand ${ }^{2}$ \\ ${ }^{1}$ Central China Normal University, Wuhan, China \\ ${ }^{2}$ Shandong University, Jinan, China \\ Email: *james.mario@live.fr
}

How to cite this paper: Azou-Passonda, M., Hong, W., \& Ferdinand, D.-K. F. (2019). Evidence of the Positive Impact of SouthSouth Cooperation in the Field of Natural Resources: The Specific Case of Sino-Central African Relations. Open Journal of Political Science, 9, 459-471.

https://doi.org/10.4236/ojps.2019.93025

Received: May 6, 2019

Accepted: May 31, 2019

Published: June 3, 2019

Copyright $\odot 2019$ by author(s) and Scientific Research Publishing Inc. This work is licensed under the Creative Commons Attribution International License (CC BY 4.0).

http://creativecommons.org/licenses/by/4.0/

(c) (i) Open Access

\begin{abstract}
In this article, we highlight people's appreciation of the positive impact of South-South relations. This study is based on data collected from a survey conducted in 2018 with 624 people. Through this study, we study how the actions led by China in the field of natural resources in CAR have impacted in the country and on local people. We note that the presence of a foreign power in the field of natural resources is conditioned by the achievement of certain actions in quite diverse fields. Also, no results indicate that China has conducted many actions in CAR that have had a positive impact on the sample. Through this study, we show the importance of diversifying partnerships through South-South relations. We found that China does not condition its interventions by political or social requirements. China's relations with CAR, as with all other African countries, are based on the principle of win-win cooperation. Beyond France and China, this article concerns others states wishing to invest in the Central African Republic (also in all Africa countries). It invites them to adopt the principle of mutually beneficial cooperation in the development of a poor country.
\end{abstract}

\section{Keywords}

South-South Relations, Natural Resources, Impact, China, Central African Republic

\section{Introduction}

One of the most controversial debates in international relations is China's pres- 
ence in Africa. Diaby (2014) believes that beyond trade, Africa has become a prime target for Chinese investment. He believes that the development of actions by China in Africa is a kind of stepping stone into the globalization strategy of large Chinese companies. This stagey is encouraged by the China authorities. Niquet-Cabestan (2006) believes that China sometimes considers Africa as a huge field of exploitation allowing him to be exercising globalization. She thinks that beyond legal exchanges, Chinese interests would be involved in illegal trafficking in several areas (wood, peach, ivory and diamonds). Moreover, some authors have spoken of a certain Western willingness to "socialize" China to Western practices in Africa (Viltard, 2012). This implies on the part of the Western powers strategies to enter into compromises with China on the basis of legitimate interests. Also, this socialization can be by the transformation of the will and preferences of China, or its involvement in bilateral and multilateral institutional constraints (Gallagher, 2011). Their goal is to socialize China to the already established order; that is, the consensual approaches that develop at the expense of Africa's development. Meanwhile, authors believe that the Chinese presence in Africa is a major risk for these states. Botz (2012) explains that China has already become a major capitalist power. Capitalism has its own characteristics and its modes of operation that cannot get African countries out of underdevelopment for more than sixty years of independence. Yu (2012) considers Chinese capitalism as a "bureaucratic capitalism." According to him, the bureaucratic capitalists with many small communist princes managed to dominate the heart of the Chinese capitalist economy. Also, they managed to form the nucleus of the new bourgeoisie that runs the Chinese state. Au Loong Yu explains that the characteristic of today's Chinese capitalism is constituted by the using of the party and the state to control the capitalist enterprises, to exploit the workers and to make profits which means that China also maintains social classes and therefore social and state inequalities. As a result, China would not be different from Western capitalized countries, and it would eventually engulf African countries.

Some authors such as Gazibo and Chantal (2011) consider that the irruption of China within the IO does not represent, as one would tend to believe, the socialization to supranational norms and rules. The Chinese presence gives it a new argument in favor of peaceful development. In this way, China will play a constructive role in maintaining stability and peace in its peripheral regions and the world. John J. Mearsheimer believes that waiting for the socialization of a great emerging power like China would be just lost. The risk of the presence of emerging countries like China lies in the fact that these countries end up imposing their conditions, demanding the re foundation of the institutions on their own criteria. And this comes down to introducing the fox into the henhouse (Johnston, 2003). In this way, the ambitions of China are those of a "developer state" (Jean-Louis Thiebault, 2011). This is what explains his actions would concrete development in Africa. Regarding foreign investment in Africa in general, 
the People Republic of China has an undeniable cost advantage over other competitors. For the development of infrastructure, Western companies whose costs are more than $50 \%$ higher than Chinese offers, can only be sliced off ( $\mathrm{Ni}$ quet-Cabestan, 2006). According to Philippe (2008), Sino-African relations create many areas of freedom and resources for African states diversifying their partnership, even if they carry risks and opportunities for the development of the African continent. He sees beyond transformations in Africa, the factor of the emergence of a multipolar world. According to Le Goff (2017), Africa is for China a major import market that is essential to develop and maintain on favorable terms. The other powers put forward their policies of interference in the name of political and social considerations. In this way, it considers that China, out of all political or social considerations, immediately perceives the need for the exporting African countries to be able to benefit from efficient road and port infrastructures.

Of all these theoretical arguments, there is no empirical evidence on the concrete appreciation of African populations, regarding the positive impact of China's actions in the area of natural resources. In this article, we highlight the appreciation of local people on the positive impact of relations between China and Central Africa in the field of natural resources. This article is based on a survey conducted in Bangui (CAR) between January and April 2018. This survey was conducted on the comparative assessment of the impact of France and China. On the basis of this survey, we build measures of actions carried out in CAR in the context of South-South relations. Also, we study how these actions have an impact on people's lives in CAR and their perception of relations with China, which is a communist country. We consider South-South relations as a set of multi-dimensional relations between China and CAR, involving natural resources, techniques, economics, etc. the presence of China in CAR gives rise to actions that have a positive impact as well as those that have a negative impact. This article is devoted to the positive aspect of its presence in the field of natural resources in CAR.

We believe that all actions by foreign powers in CAR, whatever the area of intervention, are and remain the equitable consideration for the exploitation of natural resources. The actions of foreign companies in the field of natural resources in CAR are governed by Article 17 of the Mining Code. This article requires the company to do special attention to harmonious integration of the project in CAR. This particular attention translates into giving priority related to many fields (health, environment, youth and sport, arts and culture, housing, infrastructure roads and railways, and permanent dialogue with local populations and the state). Consequently, the signature of any mining convention is accompanied by a set of specifications. These specifications consist in the construction of modern schools and health centers, as well as the provision of social and sanitary assistance, the development of sport, arts and culture. We cite as an example the conclusion of a contract for five mining permits with a Chinese 
company in 2017. In this case, the managing director of the Chinese company ThienPaoSarl reassured the Government that "Health centers and schools to build are taken into account for the benefit of the local population" (Krock, 2017). We believe that local people appreciate the actions of China in CAR. Among the actions led by China in CAR, among others, there are the construction and rehabilitation of public buildings, training for administrative staff and donations. We also find that these actions have a positive impact on people's feelings in CAR.

\section{Theoretical Framework}

What are the actions carried out by China in Central African Republic? What is the impact of these actions on the development of the Central African Republic? The theoretical framework of this article is determined in two cases. First, we describe the actions taken in return for the exploitation of natural resources in CAR. Second, we discuss the impact of these actions on the development of Central African Republic. This study has an implication for China and the CAR because it is part of the development of South-South relations linking two states with diametrically opposed ideologies. According to constructivist theory, when actors change the rules and norms of international interaction through their practices, the change in world politics occurs. In his book "Anarchy is what states make of it: the Social Construction of power politics", Wendt (1992) said that international relations was inter-identity relations and if states want the world to be anarchic then it will be. The state has basic needs related to its nature as political unity such as autonomy, economic well-being, security instinct, etc. All this leads the state to act in a selfish manner in its relations with other states, in the initial stages of interaction. Alexander Wendt (1995) considers that over time, the selfish inclinations of states will still not dominate, as states will learn to cooperate with one another. Interactions between states can lead actors to their significant redefinition that may involve a transformation of intersubjective space that advocates greater cooperation. That is why he believes that actors always come to develop identities that encompass each other as an integral part of oneself. In this way, the structure has effects and evolves only by the agents and their practices. In "Social Theory of International Politics", Wendt (1999) considers that the ideas creating interests and identities are constituted in an "intersubjective" way; because it is the result of the constant interaction between states. For Wendt, it is the process of construction or social constitution that determines international politics, not structure. Constructivism gives the possibility of transforming the state system to make it more just and peaceful through the ideas, norms and culture; or more concretely to contextualize with the wording of what is the "good" (Audie et al., 1999). The constructivism doesn't see the world "as it is" as doing the realist theory, because the world is the result of a process or movement that constructs it socially. Therefore, various social practices transform the world constantly on the basis of "intersubjective ar- 
rangements." In his book World of Our Making: Rules and Rule in Social Theory and International Relations published in 1989, Nicolas Onuf also emphasized the "intersubjective arrangements." He stated that structural realism was unable to explain these changes. First, he demonstrated how the "intersubjective understanding" (Griffiths et al., 2008) guided in the past the actions of decision-makers in the post-war liberal world economy. Then, he explained how the outcome of the missile crisis in Cuba in 1962 was linked to the development of mutual arrangements. Finally, he showed how the standard of racial equality spread into world politics and eventually contributed to the demise of apartheid in 1991. The presence of foreign powers such as China in natural resources in CAR is part of mutual arrangements with Central African Republic. These arrangements can only be consolidated by mutual willingness based on the impact of these arrangements in their development.

\section{Methodological Framework}

We believe that this study is the first to use statistical data to explain local people's appreciation of the impact of activities lead by China in the field of natural resource in CAR. The analysis is based on data from an individual survey collected in 2018. 624 respondents to this survey are the sample of this study. The sample was composed of politicians and community leaders, academia and citizens chosen at random, persons who work in some Central African administrations and INGOs. Participants are grouped by gender (male, female). Quantitative data were analyzed mainly by gender. In function, of the kind, the data are divided equally 312 men and 312 women. The data are divided into four equal groups according to the slice age of participants: between 18 and 24, 25 and 34, 35 and 44 and between 45 and 55 years. The youngest participant is between 18 and 24 years old group and the oldest in the 45 to 55 age group, an average of 23.92. In each case, 326 participants (or 52.2\%) are between the ages of 18 and 24; 183 participants (29.3\%) are between 25 and 34 years old; 69 participants (11.1\%) are between 35 and 44; and 46 participants (7.4\%) are between 45 and 55 years old. Gender represents the categories of the dependent variable. The various actions carried out by China constitute the independent variables. We perform a principal component factor analysis to measure the population's appreciation of the different actions taken by China in the field of natural resources in CAR. Bernier (1985) believes that factor analysis can also be used to measure the validity of certain scales of opinion or attitudes. Stafford and Bodson (2006) consider that principal component analysis is usually an exploratory factor analysis to better expand and understand the problem. The component analysis leads to factor analysis although these are two distinct but complementary approaches. Therefore, these are two expressions of the same method. This method allows us consequently, to determine the causal link existing between the actions carried out and the development of the CAR, represented by the appreciation of the CAR's population. 


\section{Results}

The following Table 1 explains the appreciation of Central Africans in relation to the actions carried out by China in the field of natural resources in CAR. The Table 1 is divided into four columns and includes two types of actions related to the exogenous development, and actions are tied to endogenous development.

Actions have led China in the CAR met in a hierarchical manner in column 1. Shares 1 include those related to the exogenous development of CAR. Column 2 includes the coefficients of the different actions placed in order of magnitude. Column 3 presents the variance explained by the actions taken. All the actions carried out by China in CAR totaled $71.2 \%$ of the satisfactory appreciation of Central Africans. Thus, actions 1 represent $48.8 \%$ of the variance and Actions 2 represent $22.4 \%$. 28.8\% remain unexplained. But, it is impossible to resume the data collection in the CAR now. The last column includes the internal variance, after rotation.

\subsection{Actions of Exogenous Origin}

China advocates the principle of mutually beneficial relations with Africa (Niquet-Cabestan, 2006). The concept of mutual benefits implies many factors. There is the payment a sum called "Signature Bonus" during the signature of the mining conventions. This sum is paid as an investor's contribution to the Mining Development Fund (Loi No. 09/005, 2009). Also, among other things, there are the construction and rehabilitation of public infrastructure. We present in this section the few agreements signed under the principle of cooperation with mutually advantageous benefits. The impact of these actions depends on the concerted effort of both partners and especially the genius of China.

Table 1. Appreciation of Central Africans relating to the actions carried out by China (Dependent Variable: Gender).

\begin{tabular}{|c|c|c|c|}
\hline \multirow{2}{*}{ Actions in the CAR } & \multirow{2}{*}{ Coefficients } & \multicolumn{2}{|c|}{ Variance in $\%$} \\
\hline & & Real & Internal \\
\hline 1 & 2 & 3 & 4 \\
\hline \multicolumn{4}{|c|}{ Actions I: Actions linked to an exogenous development } \\
\hline 1) Buildings & .932 & & \\
\hline 2) Win-win Exploitation & .923 & & \\
\hline 3) Donations & .829 & 48.8 & 68.5 \\
\hline 4) Project Financing & .819 & & \\
\hline
\end{tabular}

Actions II: Actions linked to endogenous development

1) Financial Support $\quad .830$

2) Formations $\quad .724$

$22.4 \quad 31.5$

3) Support Scientific Research

.690

Total :

71.2

100 


\subsection{Construction and Renovation of Public Works}

For the construction and rehabilitation of public works, we found that China has carried out several actions. China's cooperation with CAR led to the construction of two hospitals in CAR. There is the Sino-Central African Friendship Hospital built in 1983 and the Elisabeth Domitien Hospital built in 2011. China has also rebuilt the Sapéké Bridge through an interest-free loan from the Chinese Government. The Sapéké Bridge is a strategic bridge to the south exit of the capital Bangui. It connects the 2nd and 6th district of the capital and the capital with all the southwestern regions of CAR. It is the first bridge ever built in the country that meets modern construction standards, with a 100 -year viability (Luka, 2018). There is also the Administrative Building which houses three ministerial departments of the CAR, the Sportive Complex Barthélémy Boganda stadium and social housing. In 2016, an electrification project for the city of Bangui began to be launched. This allowed the installation of solar panels for public lighting in Bangui police stations, university and some streets (N'Gopot, 2016). The solar irradiation in CAR is estimated at $5 \mathrm{kWh}$ /square meter per day on average spread over the whole territory (ECCAS and CEMAC, 2014). But, the supply of electricity is still far below demand. The electrification rate in CAR is only $3 \%$. However, the hydropower potential of CAR is estimated at more than 2,000 megawatts (UNDP, 2017).

\subsection{Exploitation of Natural Resources on a Win-Win Basis}

We found that for the case of oil exploitation, China negotiated on the basis of $50 \%$ for CAR and 50\% for China (Le Facteur, 2018). In 2012, the oil permit was granted for the Boromata oil site in the Birao area, near the border with Chad. It is estimated that CAR's oil reserves in the north of the country may be more than 5 billion barrels (Brown, 2013). There are also oil reserves in other parts of CAR such as the East (not far from Djema), the West (near Carnot), and even the Center. It was in 2007 that China, through PTI-IAS and PTI-AL, made its appearance in the oil field in CAR. PTI-IAS signed a contract for hydrocarbon research in the north of the country, around Birao. The PTI-IAS license was renewed in 2012. In 2011, PTI-AL also got a hydrocarbon exploration license for a block of 25000 square $\mathrm{Km}$ in N'Délé in the north of the CAR (WikiLeaks, 2016; RFI, 2016). In April 2011, the Chinese company China National Petroleum Corporation Group (CNPC) was authorized to restart oil exploration in other parts of CAR. These explorations concern the regions of Salamat, Bagara (on the triangular border between CAR, Sudan and South Sudan) and Doseo located between CAR and Chad (Brown, 2013).

In 2017, the Central African Government and the Chinese company ThienPaoSarl signed a contract for five mining exploration permits mentioned above. This contract involved the exploitation of natural resources in western CAR (Krock, 2017). The Chinese company DEWEY has planned to rehabilitate school and administrative buildings, as well as the construction of new roads and a 
health center (Mbaye, 2017). DEWY operates in a semi-mechanized manner, the mineral resources (diamonds and gold) in the sub-prefecture of Gadzi (southwest), on the Lobaye River in the region between Boda and Carnot. We have seen a huge influx of Chinese investors in CAR for the exploitation of natural resources these last times.

\subsection{Donations and Financing Projects}

We found that the CAR has enjoyed the support of China in Civil and military equipment. Far from claiming a systematic census of all the actions of China in CAR, here, we present some of them. In this way, in November 2017, the People Republic of China donated military equipment to the Central African Army (Africa News Info, 2017). In 2011 and 2015, China donated materials (camera, console, motorcycles, bicycle, etc.) at the Ministry of Communication. In August, a donation of equipment was granted by China to the Ministry of Communication. In 2014, the city council of Bangui received donations from China (Central African Republic Press, 2014). In 2006, China also donated a batch of equipment consisting of computer and other office equipment as well as agricultural and livestock equipment. In the medical field, China has also made many donations to the CAR. Thus, China supports some services such as the laboratory with radiology equipment, neurological equipment, etc.

With regard to project financing, we also found that China has financed several development projects in CAR. Acording to Haichao Sun, the two countries signed a 30 economic and technical cooperation agreements. About 50 development projects are on track, with an estimated cost of about 50 million USD (Journal of Bangui, 2011). In October 2016, the Chinese companies Power China and Huawa-Dong carried out feasibility studies prior to the construction of three hydroelectric sites in Lobaye. This project aims to supply the prefectures of Lobaye and OmbellaM'Poko, specifically the city of Bangui. Part of the resulting electricity could be supplied to the Republic of Congo regions as part of the Central African Power Pool Program (PEAC). This is also the case of the project of building of the Danzi Power Plant for the supply of electricity near Bangui. China's actions extend to the entire African continent. Since the 1950s, China has funded 884 projects on the continent (Xavier Auregan, 2015).

\subsection{Actions Related to Endogenous Development}

The second component consists of actions whose impact is conditioned by a specific management of Central Africans.

\subsection{Financial Support}

China's financial flows, in CAR as elsewhere, China, its financial flows in CAR and elsewhere are generally based on three types of loans, with preferential interest rates (Wang and You, 2014). The first is the Government preferential loans. These are medium or long-term credits (20 years). These credits intended 
for the Chinese company who wish to carry out activities in Africa. They have an interest rate of about 3\% and fully insured by the Chinese state. The Second is the preferential export credits. This is a medium or long-term credit (20 years). These credits are intended for the African company with an interest rate of around $3 \% .15 \%$ of the credit is to be negotiated by the African company concerned with a financial institution that completes the loan, and $85 \%$ are insured by the Chinese Government. The third is the special loans for the development of African Small and medium-sized enterprises. This type of loan is intended for African small and medium-sized enterprises in collaboration with Chinese partners. This is a fixed or variable interest rate loan depending on the negotiation, generally about $6 \%$ (Lumbi, 2008). This credit is short-term (5 years) and is provided only by the China Development Bank.

China proceeds through financial contributions to CAR through this system. The CAR received the first financial support from China in 1964. It was a zero rate loan of one billion CFA Francs (Rakotoarison, 2016). Among other things, in 2003, China granted direct budget aid to CAR totaling CFA Francs 2.5 billion (€3.8 million). In 2014, China provided $\$ 200$ million and $\$ 5$ billion in budget support, including infrastructure financing.

In 2015, China reoriented its public investment policy to all African countries. As a result of this change, the CAR benefited from the cancellation of its debts (US \$30 million) in January 2018. The partial debt forgiveness of the CAR concerning China was debts from loans granted by China between 2001 and 2005, with a repayment deadline to 2015 (Wang and You, 2014).

China has granted large and generous credits to a number of African and Asian countries, socialist and non-socialist countries. These loans are interest-free, and repayment periods range from 10 to 30 years, after 10 years of delay (Schiere et al., 2011). Reimbursement is in kind.

\subsection{Training and Support in Scientific Research}

China offers training for Central Africans in the civil and military fields. In 2009, Frederick Cook estimated that about 40 Central African Army officers travel to China each year for training (Ndenkop, 2013). The French officials meanwhile believe that China offers to the CAR from 50 to 100 training seats (Terrot, 2011).

In the civilian field, for example, we found that China organized training on the "Mineral Resource Exploration and Planning Study for the Central African Country in 2018." This training was organized for the benefit of some 20 technical staff from the Ministry of Mines and the Ministry of Planning and International Cooperation. Also, China each year hosts dozen of Central African students for professional training and diplomas. Central African students, for the most part, benefit from scholarships awarded by the Chinese Government. As a result, a significant number of Central African students have already been trained at major universities in China (Niquet and Touati, 2011). According to Niquet-Cabestan (2006), The People Republic of China also offers to many 
African countries major personnel training programs.

The impact of all these actions is determined by the appreciation of Central Africans in relation to the presence of China in CAR. In the Table 2 below, we use the analysis of ordinary least squares to test the assessment has the local population on the Chinese presence in CAR.

The test analysis is significant with a level of significance $p<0.05$. The variance of sex with respect to the predictor, represented by Appreciation of the China's presence is $0.15 \%$. The explanatory share at the population level could increase by $0.13 \%$. We observe that the coefficients of the standardized regression $[$ beta $=.121, \mathrm{t}(622)=3.03, p<.05]$ indicate that China's actions have a positive influence on the population, represented by the Gender variable. People's appreciation is linked to each of these actions led by China. We consider that the impact of training consists in improving the capacity of administrative staff. Also, the impact is the internal efficiency of the Central African public administrations, including the administrations in charge of mineral resources. We believe that the Central African students well-trained are a great asset to public and private administrations. We believe that the training of Central African defense and security forces, in which all CAR partners participate, has a positive effect in CAR. Firstly, this training makes it possible to have security agents and welltrained and experienced soldiers. Secondly, this training contributes to the return of security in the provinces of CAR. In the end, we believe that well-trained administrative executives and well-trained students contribute to the sound management of the country's natural resources and the sound management of their benefits. Moreover, we think that Good management in this way contributes to the well-being of local populations.

\section{Conclusion and Discussion}

This study highlights the principle of mutually beneficial cooperation based on the appreciation of local populations. This study proves that China has done a lot of positive impact actions in CAR. These actions are determined through mutually beneficial exploitation contracts, construction and rehabilitations of public works, financial contributions, training and support in the field of scientific research, etc.

The impact of these actions is also conclusive in CAR given the positive assessment of the sample. The impact is also visible in improving the capacity of the administrative staff as well as in the internal efficiency of the public administrations. In addition, there is a positive effect on security in some provinces as a result of the training in the security and defense level. This study has implications

Table 2. Appreciation of the people about the presence of China in CAR (Dependent variable: Gender).

\begin{tabular}{cccccc}
\hline & $\mathrm{R}^{2}$ & Adjusted $\mathrm{R}^{2}$ & $\mathrm{df}$ & Beta & $p$ \\
\hline $\begin{array}{c}\text { Appreciation of the } \\
\text { China's presence }\end{array}$ & .015 & .013 & $1 ; 622$ & .121 & .002 \\
\hline
\end{tabular}


not only for China and CAR, but also for international relations and politics. As part of the development of South-South relations, this study makes it possible to understand the importance of diversifying partnerships in all areas, including the field of natural resources. Africa trades today as much with the South as with Europe. Even emerging countries in Africa have also become significant investors in sub-Saharan Africa in mining and other sectors (Philippe, 2012). Although there is an ideological difference between the CAR and China, the actions of the latter remain without ideological or social constraint. China's relations with CAR are under realpolitik based on historical ties, the principle of mutually beneficial benefits and the absence of a colonial past. In this way, Le Goff (2017) considered that China, in its relations with African countries quickly perceives the need to build adequate infrastructures without constraint of political and social order. However, China's rapid development is strictly dependent on manufacturing activities. Therefore, it needs natural resources to maintain its breakthrough. Also, it finds in Africa outlets to sell its products (textile, electronics, etc.) and know-how (public works). Future work is needed to address the negative impact of China's presence in CAR.

\section{Conflicts of Interest}

The authors declare no conflicts of interest regarding the publication of this paper.

\section{References}

Audie, K. et al. (1999). Le constructivisme dans la théorie des relations internationales. Critique internationale, 2, 51-62. https://doi.org/10.3406/criti.1999.1540

Bernier, J.-J. (1985). Théorie des tests. In J. Stafford, \& P. Bodson (Eds.), L'analyse multivariée avec SPSS (p. 57). Quebec City: Presse de l'Université du Québec.

Brown, D. E. (2013). Oil and Natural Gas Exploration and Production: National Security Implications for the United States and China Africa's Booming Oil and Natural Gas. Carlisle, PA: United States Army War College Press.

Diaby, F. S. (2014). Stratégies des entreprises chinoises en Afrique: Quels objectifs, quelle coopération? Thesis, Nice City: Université Nice Sophia Antipolis.

ECCAS and CEMAC (2014). Livre Blanc de la CEEAC et de la CEMAC, Politique régionale pour un accès universel aux services énergétiques modernes et le développement économique et social 2014-2030 Version Finale Provisoire. Yaoundé. https://www.se4all-africa.org/fileadmin/uploads/se4all/Documents/News__Partners_ Docs/ECCAS_CEMAC_livre_blanc_energie_2014.pdf

Gallagher, J. (2011). Ruthless Player or Development Partner? Britain's Ambiguous Reaction to China in Africa. Review of International Studies, 37, 2293-2310. https://doi.org/10.1017/S0260210510001622

Gazibo, M., \& Chantal, R. (2011). Un nouvel ordre mondial made in China? Montréal: Presses de l'Université de Montréal. https://doi.org/10.14375/NP.9782760622500

Griffiths, M. et al. (2008). International Relations: The Key Concepts (2nd ed.). London: Routledge Key Guides.

Johnston, A. I. (2003). Is China a Status Quo Power? In Y. Viltard (Ed.), Qui a peur de la Chine, La contribution des théoriciens Américains à une croyance (pp. 34, 41)? Paris: 
Collection Etudes.

Krock, F. (2017). Centrafrique: Contrat de 5 Permis miniers, signé avec une société chinoise. Bangui City: CNC.

La Botz, D. (2012). China: From Bureaucratic Communism to Bureaucratic Capitalism. http://www.europe-solidaire.org/spip.php?article27049

Le Facteur (2018). Coopération Centrafricano-Russie: Un véritable levier du développement de la Centrafrique.

Le Goff, C. (2017). La Chine et l'Afrique: Lorsque l'opportunité occulte le risque, Asia Focus \#35-Programme Asie.

Loi No. 09/005 (2009). Portant Code minier de la République Centrafricaine.

Luka, R. N. (2018). Le pont Sapéké inauguré par le Président de la République à Bangui. https://www.radiondekeluka.org/actualites/politique/31103-le-pont-sap\%C3\%A9k\%C3 \%A9-inaugur\%C3\%A9-par-le-pr\%C3\%A9sident-de-la-r\%C3\%A9publique-\%C3\%A0-b angui.html

Lumbi (2008). Contribution by the Minister on the Occasion of the Presentation of the Accords Signed between the Government of the Democratic Republic of the Congo and the People's Republic of China. In R. Schiere et al. (Eds.), China and Africa: An Emerging Partnership for Development (p. 113)? Tunis: African Development Bank Group.

Mbaye, K. (2017). RCA: La chinoise DEWY se lance dans l'exploitation d'or et de diamant. https://afrique.latribune.fr/entreprises/industrie/energie-environnement/2017-10-13/rc a-la-chinoise-dewy-se-lance-dans-l-exploitation-d-or-et-de-diamant-753985.html

N'Gopot, I. L. (2016). Central Africa: The City of Bangui Illuminated by Solar Panels. http://ndjonisango.com/developpement/centrafrique-la-ville-de-bangui-illuminee-pardes-panneaux-solaires

Ndenkop, O. (2013). Centrafrique: Les raisons cachées de l'intervention française. Investig'Action. https://www.investigaction.net/fr/Centrafrique-les-raisons-cachees

Niquet, V., \& Touati, S. (2011). La Chine en Afrique: Intérêts et pratiques, Programme Afrique subsaharienne, Ifri.

Niquet-Cabestan, V. (2006). La stratégie africaine de la Chine. Politique Etrangère, Été, 361-374. https://doi.org/10.3917/pe.062.0361

Philippe, H. (2008). La Chine en Afrique, néocolonialisme ou opportunités pour le développement? Revue Internationale et Stratégique, 72, 219-230.

https://doi.org/10.3917/ris.072.0219

Philippe, H. (2012). Les nouvelles alliances Sud-Sud et le rôle des relations tricontinentales dans la crise. Revue Internationale et Stratégique, 86, 57-65.

https://doi.org/10.3917/ris.086.0057

Rakotoarison, S. (2016). Vingt ans après Bokassa. http://rakotoarison.canalblog.com/archives/2017/12/01/35919633.html

RFI (2016). Pétrole: Révélations de WikiLeaks sur deux sociétés chinoises en RCA. http://www.rfi.fr/afrique/20160206-rca-wikileaks-societes-chinoises-petrole

Schiere, R. et al. (2011). China and Africa: An Emerging Partnership for Development (p. 113)? African Development Bank Group.

Stafford, J., \& Bodson, P. (2006). L'analyse multivariée avec SPSS. Quebec City: Presse de l'Université du Québec. https://doi.org/10.2307/j.ctv5j017v

Terrot, M. (2011). Assemblée Nationale, Rapport, $N^{\circ} 3308, N^{\circ} 3309$ et $N^{\circ} 3310$. http://www.assemblee-nationale.fr/13/pdf/rapports/r3309.pdf 
UNDP (2017). Stratégie et politique énergétique, lère Partie, Rapport de diagnostic du secteur énergétique de la République Centrafricaine.

https://info.undp.org/docs/pdc/Documents/CAF/Rapport\%20de\%20diagnostic\%20du \%20secteur\%20\%C3\%A9nergie\%20RCA\%20VF.pdf

Viltard, Y. (2012). Qui a peur de la Chine? La contribution des théoriciens Américains à une croyance. Paris: Collection Etudes.

Wang, Z., \& You, T. (2014). Etat des lieux de l'investissement public de la Chine en Afrique. Techniques Financières et Développement, 117, 103-109.

https://doi.org/10.3917/tfd.117.0103

Wendt, A. (1992). Anarchy Is What States Make of It: The Social Construction of Power Politics. International Organization, 46, 391-425.

https://doi.org/10.1017/S0020818300027764

Wendt, A. (1999). Social Theory of International Politics. Cambridge: Cambridge University Press. https://doi.org/10.1017/CBO9780511612183

WikiLeaks (2016). Oil Contract between the Central African Republic and Chinese Company PTI-IAS.

https://wikileaks.org/car-mining/html/PTI-IAS-CAR-Contract/page-1.html

Yu, A. L. (2012). China's Rise: Strength and Fragility. In La Botz, D. (Ed.). Chine: Du communisme bureaucratique au capitalisme bureaucratique (pp. 1-2).

http://www.europe-solidaire.org/spip.php?article27128 